\title{
ФОРМУВАННЯ МЕДИЧНИХ БІЗНЕС-ПРОЦЕСІВ У СТОМАТОЛОГІЧНОМУ ЦЕНТРІ НА ПРИНЦИПАХ ДЕРЖАВНО- ПРИВАТНОГО ПАРТНЕРСТВА
}

\author{
${ }^{1}$ Стоматологічний медичний центр Національного медичного університету імені О. О. Богомольця, \\ м. Київ, Україна \\ ${ }^{2}$ Національна медична академія післядипломної освіти імені П. Л. Шупика, м. Київ, Україна
}

\begin{abstract}
Мета: науково обґрунтувати методологію стандартизації медичних бізнес-процесів у стоматологічному центрі на принципах державно-приватного партнерства.

Матеріали і методи. Методологію стандартизації медичних бізнес-процесів у стоматологічному центрі обґрунтовано на основі системного підходу і системного аналізу із використанням інформаційно-аналітичного методу. Інформаційною базою для ії фрормування $€$ наукові праці фрахівців із організації та управління охороною здоров'я, а також результати власних досліджень.

Результати. Основна мета радикальної зміни медичних бізнес-процесів у стоматологічному центрі на принципах державно-приватного партнерства - запровадження абсолютно нових способів виконання робіт, реструктуризація виробництва послуг, що забезпечить підвищення ефективності управління, фрінансово-господарської діяльності та якості послуг. У дослідженні здійснено обґрунтування методології структуризації діяльності стоматологічного центру; виділено основні медичні бізнес-процеси із вказанням ключових чинників, які їх фрормують; визначено вхідні та вихідні події кожної групи бізнес-процесів, а також необхідні ресурси, функції і керуючі впливи для їх реалізації. Все це забезпечує орієнтацію роботи стоматологічного центру на пацієнта, підвищує ефективність використання наявних ресурсів, покращує контроль над діяльністю медичного персоналу і забезпечує підвищення якості медичної допомоги, що в кінцевому результаті сприяє збереженню стоматологічного здоров'я населення.

Висновки. Запропонована у статті методологія стандартизації медичних бізнес-процесів, яка забезпечує формування груп бізнес-процесів при наданні стоматологічної допомоги, забезпечує пацієнторієнтовану організацію роботи стоматологічного центру, підвищує ефективність використання наявних ресурсів, покращує контроль за діяльністю медичного персоналу, забезпечує підвищення якості медичної допомоги.
\end{abstract}

КЛЮчОВІ СЛОВА: стоматологічний центр; медичні бізнес-процеси; державно-приватне партнерство.

Запропонована у статті методологія стандартизації медичних бізнес-процесів, яка забезпечує фрормування груп бізнес-процесів при наданні стоматологічної допомоги, забезпечує орієнтацію роботи стоматологічного центру на пацієнта, підвищує ефрективність використання наявних ресурсів, покращує контроль за діяльністю медичного персоналу, забезпечує підвищення якості медичної допомоги.

У сучасних економічних умовах України державна система стоматологічної допомоги перебуває у складному стані, а її адаптація до ринкових умов вимагає нових підходів та ініціатив для забезпечення іїі виживання. Механізмом для залучення додаткових ресурсів та інструментом стимулювання економічної активності державних стоматологічних закладів $€$ державно-приватне партнерство (ДПП). Партнерство держави з організаціями приватного сектора може забезпечити стоматологічні заклади новими джерелами фінансування, висококваліфікованими кадрами і сучасними високими технологіями $[3,8]$.

(с В. Д. Чопчик, Н. М. Орлова, 2019
Варто зазначити, що це партнерство має бути гармонізованим 3 національними пріоритетами у сорері охорони стоматологічного здоров'я населення, повинно доповнювати, а не підміняти державні ініціативи та інтегруватися у систему охорони здоров'я без будь-якого конфрлікту інтересів [3].

Одними 3 структуроутворювальних елементів державно-приватного партнерства у сорері охорони здоров'я на базі стратегічного альянсу органів влади, університетських клінік та приватних інвесторів повинні стати університетські стоматологічні центри. Їх створення $є$ доцільним із метою розвитку клінічної та наукової діяльності, а також для розвитку якісної стоматологічної допомоги, орієнтованої на задоволення потреб пацієнтів.

Мета роботи: науково обґрунтувати методологію стандартизації медичних бізнес-процесів у стоматологічному медичному центрі на принципах державно-приватного партнерства.

Матеріали і методи. Методологію стандартизації медичних бізнес-процесів у стоматологічному центрі обґрунтовано на основі системного 
підходу і системного аналізу із використанням інформаційно-аналітичного методу. Інфрормаційною базою для її фрормування $€$ наукові праці фрахівців із організації та управління охороною здоров'я, а також результати власних досліджень.

Результати дослідження та їх обговорення. Фундаментальне переосмислення і радикальне перепроектування бізнес-процесів 3 урахуванням запровадження у стоматологічних центрах принципів державно-приватного партнерства та 3 метою досягнення максимального ефректу виробничо-господарської та фрінансовоекономічної діяльності за такими індикаторами, як вартість, якість, сервіс і под., визначається як реінжиніринг бізнес-процесів (англ. Business process reengineering) $[1,5]$. Реінжиніринг бізнеспроцесів, як інструмент управління медичними організаціями, вперше описаний у зарубіжних дослідженнях $[10,11]$.

Наукові основи фрормування бізнес-процесів забезпечують ефективність діяльності медичних організацій та підвищення якості медичної допомоги [2, 6, 7]. Основна мета радикального перепроектування - запровадження абсолютно нових способів виконання робіт, реструктуризація виробництва послуг, що забезпечить підвищення ефективності управління, фрінансово-господарської діяльності та якості послуг. Основним методом реструктуризації $€$ «зміна організаційної системи шляхом створення комплексу бізнес-груп» $[4,6]$. На думку Х. К. Рамперсада [9], універсальна система показників об'єднує методологію збалансованої системи показників із концепціями управління якістю, навчанням і компетенціями.

Детальна характеристика і стандартизація бізнес-процесів $€$ необхідною умовою для їх успішної реалізації.

Медичні бізнес-процеси надання стоматологічної допомоги у стоматологічному центрі повинні визначатися відповідно до їх цінності для пацієнта. Першочерговим пріоритетом для пацієнта при отриманні стоматологічної допомоги $€$ встановлення правильного діагнозу. Встановлення діагнозу фрормує ланцюжок бізнес-процесів, який визначає всю подальшу послідовність взаємопов'язаних дій співробітників закладу і пацієнта як до, так і після його встановлення. Виділяють групи бізнес-процесів, орієнтовані на встановлення правильного діагнозу, що дозволяє визначити есрективну схему лікування і, як наслідок, досягти успішних результатів у лікуванні захворювання. В основному фрормують 3 групи медичних бізнес-процесів (рис. 1).

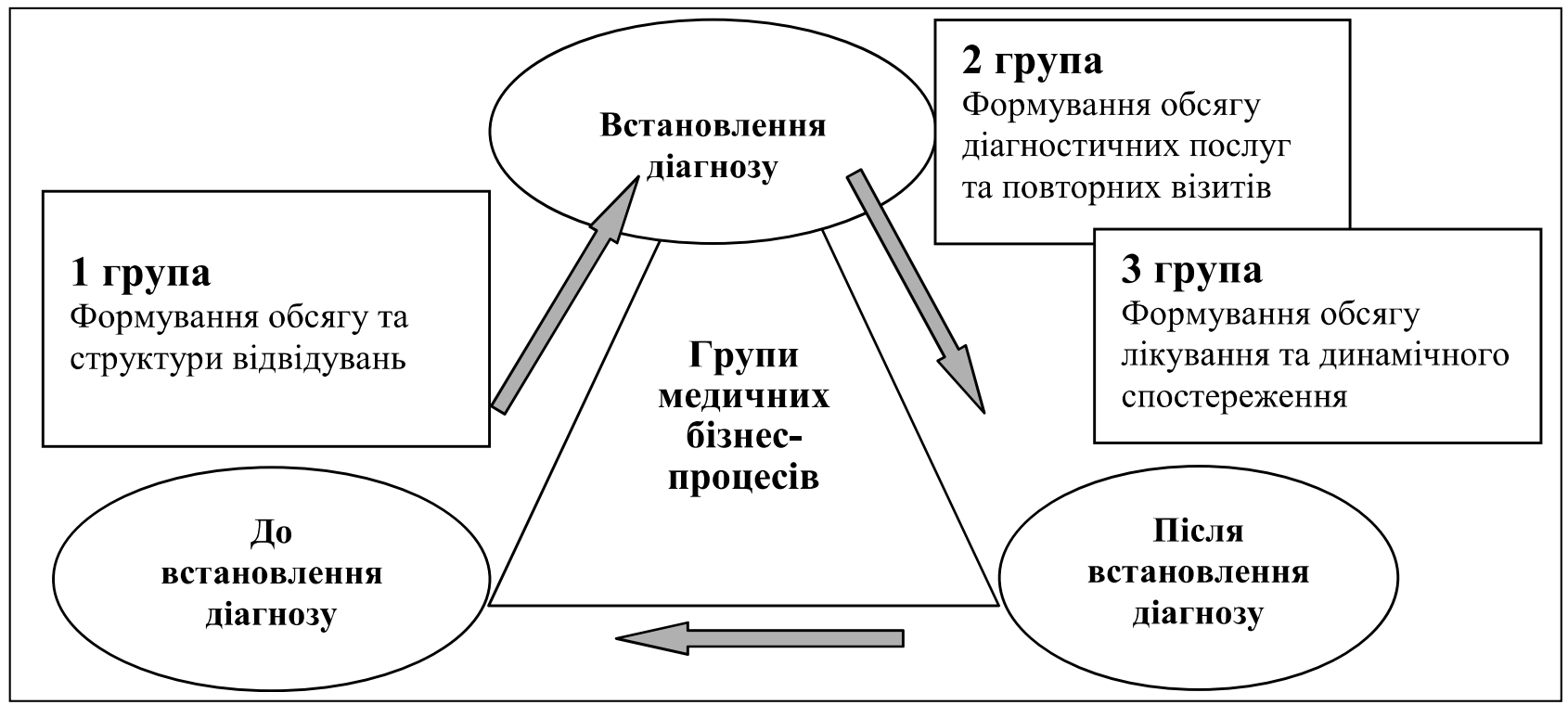

Puc. 1. Групи медичних бізнес-процесів у стоматологічному центрі.

Ключовими чинниками, які фрормують структуру груп медичних бізнес-процесів у стоматологічному центрі, є:

1) характер обслуговування (страховка, договір, безпосередня оплата);

2) програма обслуговування (обсяг послуг);

3) причина звернення (захворювання, діагностика, профрілактика);

4) характер комунікації стоматологічного центру і пацієнта (регулярність);
5) якість діагностики (обґрунтованість діагнозу, відповідність плану ведення пацієнта);

6) якість лікування (правильність обсягу лікування);

7) гнучкість у наданні медичних послуг (перезапис на прийом, заміна лікаря, послуг);

8) автоматизація стоматологічної діяльності.

Логічну послідовність представлення виділених груп медичних бізнес-процесів схематично зображено на рисунку 2. 


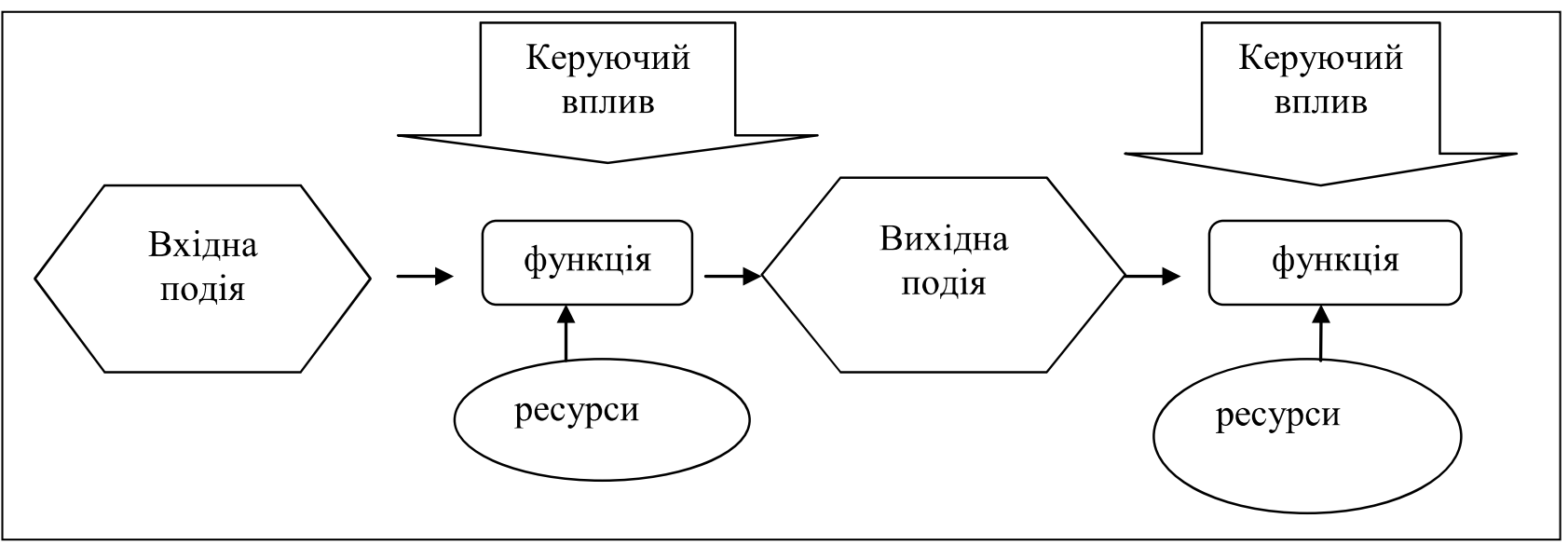

Puc. 2. Схема бізнес-процесів.

Перша група бізнес-процесів «До встановлення діагнозу» характеризується тим, що у ході виконання, включених до неї дій, для пацієнта будуть сорормовані обсяг і структура відвідувань до стоматологічного центру.

У цьому випадку як вхідні події необхідно розглядати звернення пацієнта з метою: запису на прийом, прикріплення до стоматологічного центру, отримання довідкової інфрормації.

Вхідна подія ініціює виконання співробітниками стоматологічного центру наступних фрункцій:

- первинне спілкування з пацієнтом, фрормування запису в розкладі;

- укладення угоди на надання стоматологічних послуг;

- підписання добровільної інфрормованої згоди;

- узгодження умов надання стоматологічної допомоги (час, лікар-стоматолог і т. д.);

- формування медичної карти, статистичного талона;

- контроль явки пацієнта (нагадування про візит);

- підготовка до візиту пацієнта робочого місця лікаря-стоматолога.

Керуючим впливом для реалізації цих фрункцій буде ініціативне звернення пацієнта (дзвінок або відвідування реєстратури) та/або ініціативне звернення лікаря-стоматолога (організація повторного візиту), а також посадові інструкції, внутрішні нормативні документи, у разі наявності медичної інформаційної системи - відповідна відмітка у базі даних.

Ресурсами, які реалізують фрункції цієї групи бізнес-процесів, є реєстратура, комерційний (договірний) відділ, середній медичний персонал, медична інформаційна система.

Вихідними подіями, які завершують дані бізнес-процеси, наприклад, можуть бути:

- явка пацієнта на прийом;

- відмова пацієнта від обслуговування;

- направлення на додаткове обстеження.

Друга група бізнес-процесів описується за аналогічним принципом. У цій групі вхідною подією буде вихідна подія попередніх бізнес-процесів:
- явка пацієнта на прийом;

- направлення на додаткове обстеження.

Функції:

- прийом хворого, діагностика, встановлення попереднього діагнозу, надання невідкладної допомоги;

- визначення обсягу стоматологічних послуг, їх відповідності програмі добровільного медичного страхування;

- визначення необхідності надання додаткових послуг;

- попереднє узгодження оплати додаткових послуг;

- офрормлення медичної документації;

- визначення дати повторного візиту до стоматолога (запускає вхідну подію бізнес-процесу «До встановлення діагнозу»);

- консультації інших спеціалістів, рентгенологічні, лабораторні та інші дослідження;

- аналіз результатів рентгенологічних та інших досліджень, встановлення остаточного діагнозу.

Керуючі впливи: розклад, заявка на надання стоматологічної допомоги, план ведення пацієнта, стандарт лікування, чинне законодавство, програма медичного страхування, посадова інструкція та інші внутрішні нормативні документи.

Ресурси: лікарі-стоматологи та середній медичний персонал відділень стоматологічного центру, реєстратура, діагностичні підрозділи, медична інформаційна система.

Вихідні події: направлення на консультацію до інших фрахівців, встановлення остаточного діагнозу, направлення на лікувальні процедури; на диспансерне спостереження.

Для третьої групи бізнес-процесів вхідними подіями будуть:

- встановлення остаточного діагнозу;

- направлення на лікувальні процедури;

- направлення на диспансерне спостереження.

Функції:

- надання додаткових послуг (оплата вже погоджена);

- визначення обсягу і способів лікування; 
- виконання планових лікувальних процедур і маніпуляцій;

- контроль ефрективності лікування;

- фрормування медичної статистики;

- забезпечення динамічного спостереження.

Керуючі впливи: розклад, план ведення пацієнта, стандарт лікування, чинне законодавство, програма медичного страхування, посадова інструкція, ініціативне звернення лікаря-стоматолога (виклик для динамічного спостереження), посадові інструкції та інші внутрішні нормативні документи.

Ресурси: лікарі-стоматологи та середній медичний персонал відділень стоматологічного центру, реєстратура.

Вихідні подіі: звернення пацієнта з метою запису на вторинний прийом, профілактичний огляд, консультація у лікарів-стоматологів інших спеціальностей, відмова пацієнта від обслуговування.

\section{Висновки}

Запропонована у статті методологія стандартизації медичних бізнес-процесів, яка забезпечує фрормування груп бізнес-процесів при наданні стоматологічної допомоги, забезпечує орієнтацію роботи стоматологічного центру на пацієнта, підвищує ефективність використання наявних ресурсів, покращує контроль за діяльністю медичного персоналу, забезпечує підвищення якості медичної допомоги.

Перспективи подальших досліджень полягають у використанні запропонованих бізнес-процесів при розробці оптимізованої моделі стоматологічного центру для університетської клініки, яка працює на принципах державно-приватного партнерства.

\section{Список літератури}

1. Блинов О. А. Реинжиниринг бизнес-процессов как управленческая инновация современных организаций: методологический аспект / О. А. Блинов, Г. А. Яшева // Вестн. Витебск. гос. технолог. ун-та. - 2014. - № 26. - С. 147-160.

2. Горачук В. В. Управління якістю медичної допомоги в закладі охорони здоров'я / В. В. Горачук. - Вінниця : ТОВ «Меркьюрі-Поділля», 2012. - 213 с.

3. Добагян Е. К. Факторы и современные тенденции развития ГЧП в здравоохранении на примере зарубежного опыта / Е. К. Добагян // Человеч. капитал и профессион. образование. - 2016. - № 2. - С. 75-78.

4. Зеленков Ю. А. Об измерении эфрфективности бизнес-процессов и поддерживающих их информационных систем / Ю. А. Зеленков // Управление большими системами. - 2013. - Вып. 41. - С. 146-161.

5. Златкина А. А. Методология реинжиниринга бизнес-процессов и типовые приемы её применения / А. А. Златкина, Е. Т. Гегечкори // Омский научный вестник. - 2016. - № 1. - С. 117-120.

6. Князюк Н. Ф. От менеджмента качества к стратегическому управлению медицинской организацией с использованием сбалансированной системы показателей / Н. Ф. Князюк // Менеджер здравоохранения. - 2010. № 4. - C. 21-29.

7. Орлова Н. М. Методологія системного цільового управління діяльністю амбулаторно-поліклінічного закладу /

Н. М. Орлова, І. В. Корецький // Галицький лікарський вісник. - 2013. - Т. 20, № 3. - С. 142-145.

8. Основы государственно-частного партнерства (теория, методология, практика) / В. Варнавский, А. Зельднер,

В. Мочальников, С. Сильвестров. - М. : Анкил, 2015. - 252 с.

9. Рамперсад X. К. Универсальная система показателей: Как достигать результатов, сохраняя целостность / Х. К. Рамперсад ; пер. с англ. - М. : Альпина Паблишер, 2009. - 352 с.

10. Робсон М. Реинжиниринг бизнес-процессов / М. Робсон, Ф. Уллах. - М. : Юнити-Дана, 2010. - 110 с.

11. Хаммер М. Реинжениринг корпорации: Манифест революции в бизнесе / М. Хаммер, Дж. Чампи ; пер. с англ. Ю. А. Корнилович. - М. : Манн, Иванов и Фебер, 2009. - 287 с.

\section{References}

1. Blinov, O.A. \& Yasheva, G.A. (2014). Reinzhiniring biznes-protsessov kak upravlencheskaya innovatsiya sovremennykh organizatsiy: metodologicheskiy aspekt [Reengineering of business processes as managerial innovation of modern organizations: methodological aspect]. Vestnik Vitebskogo gosudarstvennogo tekhnologicheskogo universiteta - Bulletin of Vitebsk State Technological University, 26, 147-160 [in Russian].

2. Horachuk, V.V. (2012). Upravlinnia yakistiu medychnoi dopomohy v zakladi okhorony zdorovia [Management of the quality of medical care at the institution of health care]. Vinnytsia : TOV "Merkuri-Podillia [in Ukrainian].

3. Dobagyan, Ye.K. (2016). Faktory i sovremennyye tendentsii razvitiya GChP v zdravookhranenii na primere zarubezhnogo opyta [Factors and current trends in the development of PPP in health care on the example of foreign experience]. Chelovecheskiy kapital i professionalnoye obrazovaniye - Human Capital and Vocational Education, 2, 75-78 [in Russian]. 4. Zelenkov, Yu.A. (2013). Ob izmerenii effektivnosti biznes-protsessov i podderzhivayushchikh ikh informatsionnykh system [Measuring the efficiency of business processes and their supporting information systems]. Upravleniye bolshimi sistemami - Management of Large Systems, IPURAN, 41, 146-161 [in Russian].

5. Zlatkina, A.A., \& Gegechkori, Ye.T. (2016). Metodologiya reinzhiniringa biznes-protsessov i tipovyye priyemy yeyo primeneniya [The methodology of business process reengineering and typical methods of its application]. Omskiy nauchnyy vestnik - Omsk Scientific Herald, 1, 117-120 [in Russia].

6. Knyazyuk, N.F. (2010). Ot menedzhmenta kachestva k strategicheskomu upravleniyu meditsinskoy organizatsiyey $\mathrm{s}$ ispolzovaniyem sbalansirovannoy sistemy pokazateley [From quality management to strategic management of a 
medical organization using a balanced scorecard]. Menedzher zdravookhraneniya - Health Care Manager, 4, 21-29 [in Russian].

7. Orlova, N.M. \& Koretskyi, I.V. (2013). Metodolohiia systemnoho tsilovoho upravlinnya diialnistiu ambulatornopoliklinichnoho zakladu [Methodology of system target management of outpatient-polyclinic institution activity]. Halytskyi likarskyi visnyk - Galician Medicinal Herald, 20 (3), 142-145 [in Ukrainian].

8. Varnavskiy, V., Zeldner, A., Mochalnikov, V., \& Silvestrov, S. (2015). Osnovy gosudarstvenno-chastnogo partnerstva (teoriya, metodologiya, praktika) [Basics of public-private partnership (theory, methodology, practice)]. Moscow: Ankil [in Russian].

9. Rampersad, H.K. (2009). Universalnaya sistema pokazateley: Kak dostigat rezultatov, sokhranyaya tselostnost [How to achieve results while maintaining integrity]. Moscow: Alpina Publisher [in Russian].

10. Robson, M. \& Ullah, F. (2010). Reinzhiniring biznes-protsessov [Business process reengineering]. Moscow: YunitiDana [in Russian].

11. Hammer, M. \& Champi, J. (2009). Reinzheniring korporatsii: Manifest revolyutsii v biznese [Reengineering Corporation: The Manifesto of the Revolution in Business]. Kornilovich, Yu.A. (Trans). Moscow: Mann, Ivanov i Feber [in Russian].

\section{ФОРМИРОВАНИЕ МЕДИЦИНСКИХ БИЗНЕС-ПРОЦЕССОВ В СТОМАТОЛОГИЧЕСКОМ ЦЕНТРЕ НА ПРИНЦИПАХ ГОСУДАРСТВЕННО-ЧАСТНОГО ПАРТНЕРСТВА}

В. Д. Чопчик ${ }^{1}$, Н. М. Орлова ${ }^{2}$

${ }^{1}$ Стоматологический медицинский центр Национального медицинского университета имени А. А. Богомольца, г. Киев, Украина

${ }^{2}$ Национальная медицинская академия последипломного образования имени П. Л. Шупика, г. Киев, Украина

Цель: научно обосновать методологию стандартизации медицинских бизнес-процессов в стоматологическом центре на принципах государственно-частного партнерства.

Материалы и методы. Методология стандартизации медицинских бизнес-процессов в стоматологическом центре обоснована на основании системного подхода и системного анализа с использованием информационно-аналитического метода. Инфрормационной базой для ее фрормирования выступили научные работы специалистов по организации и управлению здравоохранением, а также результаты собственных исследований.

Результаты. Основная цель радикального изменения медицинских бизнес-процессов в стоматологическом центре на принципах государственно-частного партнерства - внедрение совершенно новых способов выполнения работ, реструктуризация производства услуг, что обеспечит повышение эфффективности управления, фринансово-хозяйственной деятельности и качества услуг. В исследовании осуществлено обоснование методологии структуризации деятельности стоматологического центра; выделены основные медицинские бизнес-процессы с указанием ключевых фракторов, которые фрормируют; определенные события на входе и выходе каждой группы бизнес-процессов, а также необходимые ресурсы, функции и управляющие воздействия для их реализации. Все это обеспечивает ориентацию работы стоматологического центра на пациента, повышает эффрективность использования имеющихся ресурсов, улучшает контроль над деятельностью медицинского персонала и обеспечивает повышение качества медицинской помощи, что в конечном итоге способствует сохранению стоматологического здоровья населения.

Выводы. Предложенная в статье методология стандартизации медицинских бизнес-процессов, которая обеспечивает фрормирование групп бизнес-процессов при оказании стоматологической помощи, обеспечивает пациенториентированную организацию работы стоматологического центра, повышает эфроективность использования имеющихся ресурсов, улучшает контроль за деятельностью медицинского персонала, повышение качества медицинской помощи.

КЛЮЧЕВЫЕ СЛОВА: стоматологический центр; медицинские бизнес-процессы; государственночастное партнерство.

\section{FORMATION OF MEDICAL BUSINESS-PROCESSES IN THE DENTAL CENTER ON THE PRINCIPLES OF PUBLIC-PRIVATE PARTNERSHIP}

V. D. Chopchik ${ }^{1}$, N. M. Orlova ${ }^{2}$

${ }^{1}$ Dental Medical Center of O. Bohomolets National Medical University

${ }^{2} P$. Shupyk National Medical Academy of Postgraduate Education

Purpose: to scientifically substantiate the methodology of standardization of medical business-processes at the dental center, on the principles of public-private partnership.

Materials and Methods. The methodology standardization of medical business-processes at the dental center was developed on the basis of a systematic approach and system analysis using information-analytical method. The information base for its formulations were scientific works of specialists in the organization and management of health care, and the results of own research. 
Results. The main objective of the radical change of medical business processes in the dental center on the principles of public-private partnership is the introduction of completely new ways of carrying out the work, restructuring of the production of services, which will increase the efficiency of management, financial and business activities and the quality of services. The research substantiates the methodology of structuring the activities of the dental center. The main medical business processes are identified with a list of key factors that shape them; defined events at the input and output of each group of business processes, as well as the necessary resources, functions and management impacts for their implementation. All this provides orientation of the dental center to the patient, increases the efficiency of resource use, improves control over the activities of medical personnel and improves the quality of medical care, which ultimately helps to improve the dental health of the population.

Conclusions. The methodology of standardization of medical business processes, which ensures the formation of groups of business processes in the provision of dental care, provides a patient-oriented organization of the work of the dental center, increases the efficiency of the use of available resources, improves control over the activities of medical personnel, and improves the quality of medical care.

KEY WORDS: dental center; medical business-processes; public-private partnership.

Рукопис надійшов до редакції 28.02.2019 р.

Відомості про авторів:

Чопчик Віталій Дмитрович - кандидат медичних наук, в. о. заступника директора з медичної частини Стоматологічного медичного центру Національного медичного університету імені О. О. Богомольця.

Орлова Наталія Михайлівна - доктор медичних наук, професор кафедри медичної статистики Національної медичної академії післядипломної освіти імені П. Л. Шупика; тел.: +38(044) 278-77-79. 